University of Pennsylvania Carey Law School

Penn Law: Legal Scholarship Repository

Faculty Scholarship at Penn Law

$1-24-2008$

\title{
The Argentine Financial Crisis: State Liability Under BITs and the Legitimacy of the ICSID System
}

\author{
William W. Burke-White \\ University of Pennsylvania Carey Law School
}

Follow this and additional works at: https://scholarship.law.upenn.edu/faculty_scholarship

Part of the Banking and Finance Law Commons, Commercial Law Commons, Dispute Resolution and Arbitration Commons, Finance and Financial Management Commons, International Economics Commons, International Law Commons, International Relations Commons, Law and Economics Commons, and the Public Economics Commons

\section{Repository Citation}

Burke-White, William W., "The Argentine Financial Crisis: State Liability Under BITs and the Legitimacy of the ICSID System" (2008). Faculty Scholarship at Penn Law. 193.

https://scholarship.law.upenn.edu/faculty_scholarship/193

This Article is brought to you for free and open access by Penn Law: Legal Scholarship Repository. It has been accepted for inclusion in Faculty Scholarship at Penn Law by an authorized administrator of Penn Law: Legal Scholarship Repository. For more information, please contact PennlawIR@law.upenn.edu. 


\section{THE ARgENTINE FINANCIAL CRISIS: \\ STATE LiABILITY UNDER BITS AND THE LEGITIMACY OF THE ICSID SysteM

\author{
William W. Burke-White
}

\section{INTRODUCTION}

Over the past two decades, the international investment law regime has expanded dramatically, particularly through an extraordinary increase in the number of bilateral investment treaties (BITs) that confer direct rights on transnational investors. ${ }^{1}$ With well over 2000 such treaties in force today, investors have considerable legal opportunities to recoup loses caused by host-state impairment of transnational investments. This global expansion of BITs has been accompanied by the development of the International Center for the Settlement of Investment Disputes (ICSID), a forum under the auspices of the World Bank that allows for direct investor-state arbitration, generally of claims arising out of alleged violations of BITs. Today, there are 143 states parties to the ICSID Convention and investors in those states can bring claims directly against host-states for damages. In the past few years, the ICSID caseload has also expanded, with over 120 cases pending as of late 2007. Taken collectively, these two developments provide investors with unprecedented protections against host-state impairment of transnational investments.

More than forty of the cases presently pending before ICSID have been brought against the Republic of Argentina and assert that the Argentine government's response to the catastrophic financial crisis that hit that country in late 2001 and 2002 impaired investor rights secured under a number of Argentina's BITs. These cases are of extraordinary importance, not just because of the immense financial liability to which

\footnotetext{
* Assistant Professor of Law, University of Pennsylvania Law School. Ph.D. (Cambridge, 2006); J.D. (Harvard, 2002), M.Phil. (Cambridge, 2000), B.A. (Harvard, 1998). While the author has served as an expert witness for the Government of Argentina in some of the cases noted herein, this work reflects his independent academic opinion and is not indicative of the policy of the Government of Argentina. The author can be reached at wburkewh@law.upenn.edu

${ }^{1}$ As the United Nations Conference on Trade and Development (UNCTAD) reported in a 2000 study, the "number of treaties quintupled during the decade [of the 1990s], rising from 385 at the end of the 1980s to 1,857 at the end of the 1990s. United Nations Conference on International Trade and Development, Bilateral Investment Treaties 1959-1999 (2000), UN DOC UNCTAD/ITE/IIA/2, at iii.
} 
they expose Argentina, but also because, in response, Argentina has invoked a broad set of legal arguments about the rights of states to craft policy responses to extraordinary situations such as a massive financial collapse. Argentina has asserted two separate arguments that go to the heart of the sovereign prerogative of states to develop fundamental policies to address exceptional circumstances, one based on treaty law and one based on customary international law. Argentina's treaty law argument invokes the non-precluded measures (NPM) provisions of Argentine BITs that exempt certain actions taken by states in response to extraordinary circumstances from the substantive protections of the treaties. Argentina's customary international law argument has asserted that the doctrine of necessity precludes the wrongfulness of Argentina's actions in response to the crisis. These arbitrations thus test the both the limits of state freedom of action and investor protections under the BIT regime in exceptional circumstances.

The resulting jurisprudence of the ICSID Tribunals in four cases against Argentina decided by early 2008 is deeply problematic, due in part to poor legal reasoning and questionable treaty interpretation and, in part, to the contradictory holdings in the awards issued to date. In fact, three of the four Tribunals have held Argentina fully responsible for harms to investors notwithstanding the extreme financial crisis it faced, whereas the remaining Tribunal absolved Argentina of much of its responsibility for those acts. This article asserts that the tree ICSID Tribunals that have held Argentina liable failed to fully recognize the treaty-based exceptions provided for in the NPM clauses of Argentina BITs and have interpreted the customary law doctrine of necessity extremely narrowly-so narrowly as to make it essentially unavailable to any state. Particularly when taken in light of the Report of the Annulment Committee in the case of CMS v. Argentina which rejected the legal reasoning of the arbitral tribunal in that case but failed to overturn the substantive outcome of the Tribunal's award, this problematic jurisprudence presents a serious challenge to the legitimacy of the BIT regime and the ICSID system more generally. While scholars have long noted a legitimacy deficit in investor-state arbitration and predicted a crisis in the system, the Argentine cases may well be precipitating that crisis both because these cases touch on the most fundamental policy choices of states and because, for the first time, an Annulment Committee appears to be catalyzing a rethinking of investor-state arbitration more generally through its own jurisprudence. 
This article argues that the awards issued in the Argentine cases to date exhibit extremely poor legal analysis with substantive outcomes that do not reflect either the text of Argentina's BITs nor the intent of the state parties to those BITs. Moreover, the article suggests that these awards have the potential to undermine the legitimacy and authority of BIT arbitrations before ICSID and that, as a result of the CMS Annulment Committee Report, some of the basic premises of investor state arbitration must be reconsidered.

The article proceeds as follows: Part II provides a brief background to Argentina's financial crisis and the cases pending against it. Part III analyzes Argentina's legal arguments in these cases, particularly its invocation of NPM clauses in the U.S.Argentina BIT and the customary law defense of necessity. Part IV considers the contradictory approaches and decisions in the four ICSID awards decided in the Argentine cases as of early 2008. Part V analyzes the Annulment Committee Decision in $C M S$ v. Argentina and suggests that the Committee may well have intended to prompt a legitimacy crisis in the ICSID system and a more fundamental rethinking of state liability under BITs.

\section{The ARgentine FinAnCiAl CRisis And the Government’s ResPonse}

In the last weeks of 2001, Argentina experienced a financial collapse of catastrophic proportions. $^{2}$ In one day alone, the Argentine peso lost $40 \%$ of its value. ${ }^{3}$ As the peso collapsed, a run on banks followed. According to The Economist, throughout the collapse, "income per person in dollar terms...shrunk from around $\$ 7,000$ to just $\$ 3,500$ " and "unemployment [rose] to perhaps 25\%."4 This economic chaos meant that, by late 2002, over half the Argentine population was living below the poverty line. ${ }^{5}$ The crisis

\footnotetext{
2 See Paul Blustein, And the Money Kept Rolling In (And Out): Wall Street, the IMF And the BANKRUPTING OF ARGENTINA 1-2 (2005). For a discussion of the economic background to the collapse, see Mario Damill, Roberto Frenkel \& Martin Rapetti, The Argentinean Debt: History, Default and Restructuring 2-18 (Apr. 2005, revised Aug. 2005) (unpublished CEDES working paper), available at http://www0.gsb.columbia.edu/ ipd/pub/Frenkel_SDR_Eng.pdf.

3 See Certificate Concerning the State of Necessity in Argentina, Guillermo Nielsen, Secretary of Finance of Argentina, Jan. 2003, \11 [hereinafter Nielsen Declaration] (on file with author). Certification was made by the Argentine government to the courts adjudicating the debt cases and the ICSID cases arising out of the economic crisis.

4 Argentina's Collapse: A Decline Without Parallel, The ECONOMIST, Mar. 2-8, 2002, at 26, 26.

5 Nielsen Declaration, supra note 3, ๆ 5; see also Slump Turns Jobless Argentines Into Scavengers, N.Y.
} 
soon spread from the economic to the political sphere. In December 2001, one day of riots left 30 civilians dead and led to the resignation of President Fernando de la Rua and the collapse of the government. A "tragicomic spectacle of a succession of five presidents taking office over a mere ten days” followed. ${ }^{6}$

In response to the crisis, which has been likened to the Great Depression of the 1930s in the United States, ${ }^{7}$ Argentina adopted a number of measures to stabilize the economy and restore political confidence. Among these efforts was a significant devaluation of the peso through the termination of the currency board which had pegged the peso to the U.S. dollar, the pesification of all financial obligations, ${ }^{8}$ and the effective freezing of all bank accounts through a series of measures known collectively as the Corralito. ${ }^{9}$

Though these measures offered a long-term prospect of restored economic confidence and stability, they also imposed immediate and painful costs on all participants in the Argentine economy, including foreign investors. While Argentine citizens had little legal recourse, many foreign investors who were harmed by Argentina's response to the crisis sought legal protection under the regime of bilateral investment treaties (BITs), which Argentina had entered into during the 1980s and 1990s. ${ }^{10}$ Such treaties offered investors guarantees including the internationalization of contractual breaches, national treatment, and most-favored nation protections. ${ }^{11}$ In addition, these treaties often provided investors the possibility of direct investor-state arbitration before the International Centre for Settlement of Investment Disputes (ICSID). ${ }^{12}$

\footnotetext{
TIMES, Sept. 21, 2002, at $\S 1$, at 14. Beginning in late November 2000, massive strikes swept Argentina. On November 23, 2000, "[m]illions of workers stayed off their jobs in the largest national strike in years as a union-led protest against government austerity measures virtually paralyzed the country.” Argentina: Strikes Against Austerity, N.Y. TIMES, Nov. 25, 2000, at A6.

6 BLUSTEIN, supra note 2, at 1.

7 See, e.g., A Survey of Capitalism and Democracy: Liberty's Great Advance, ECONOMIST, June 28, 2003, at 4, 6 ("Argentina has endured an economic collapse to match the Great Depression of the 1930s....").

8 See Law No. 25561, Jan. 7, 2002, 29810 B.O. 1, available at

http://infoleg.mecon.gov.ar/infolegInternet/verNorma.do?id=71477.

9 See Decree No. 1570, Dec. 3, 2001, 29787 B.O. 1, available at

http://infoleg.mecon.gov.ar/infolegInternet/verNorma.do?id=70355. For reference to the measures as the Corralito, see, for example, CARINA LOPEZ, STANDARD \& POOR's, THE ARGENTINE CRISIS: A

Chronology of Events After the Sovereign Default (Apr. 12, 2002),

http://www.standardandpoors.com/europe/francais/Fr_news/Argentine-Chronology-of-Events_12-0402.html.

${ }^{10}$ For a list of Argentine BITs, see U.N. Conference on Int'l Trade \& Dev. [UNCTAD], Bilateral Investment Treaties 1959-1999, at 26-27, U.N. Doc. UNCTAD/ITE/IIA/2 (Dec. 2000) (prepared by Abraham Negash), available at http://www.unctad.org/en/docs/poiteiiad2.en.pdf.

11 For a discussion of protections often found in BITs, see M. SORNARAJAH, THE INTERNATIONAL LAW ON FOREIGN INVESTMENT 233-58 (2004); Andrew Guzman, Book Note, The International Law on Foreign Investment, 6 EUR. J. INT’L L. 612, 613-14 (1995).

12 The International Centre for Settlement of Investment Disputes (ICSID) has been created under the
} 
For investors harmed by Argentina's response to the economic crisis, the possibility of direct arbitration against the Argentine government for breaches of BITs offered a potentially promising means to recoup losses suffered during the crisis. Claims framed as a violation of a BIT could be brought directly against Argentina through ICSID. Only limited means are available to challenge ICSID awards and such awards are generally perceived as enforceable in national courts. Not surprisingly, then, Argentina has become subject to no fewer than forty-three ICSID arbitrations brought by investors who assert that Argentina's response to the crisis harmed investments protected by various BITs. ${ }^{13}$ Argentina's potential liability from these cases alone could be greater than U.S. \$8 billion, more than the entire financial reserves of the Argentine government in 2002. ${ }^{14}$ Some have speculated that the total value of potential claims against Argentina could reach U.S. $\$ 80$ billion. ${ }^{15}$

III. ARgentina’s Legal ARguments For Policy FleXibility In ReSPonse TO AN ECONOMIC CRISIS

In response to this onslaught of ICSID arbitrations, Argentina has, not surprisingly, denied that its actions in fact caused the harms asserted by investors. ${ }^{16}$ Argentina's legal approach has also gone considerably further, asserting two broad arguments which raise deeper structural questions about the rights of states to respond to extraordinary situations such as a massive financial crisis. Specifically, Argentina has invoked the NPM clauses of its BITs and has asserted that the state of necessity in customary international law precludes the wrongfulness of its actions. These arguments suggest, first, as a matter of treaty law and, second, as a matter of customary law, that states in circumstances such as

auspices of the World Bank to hear such cases. See Convention on the Settlement of Investment Disputes Between States and Nationals of Other States, opened for signature Mar. 18, 1965, 17 U.S.T. 1270, 575 U.N.T.S. 159 [hereinafter ICSID Convention], available at http://www.worldbank.org/icsid/basicdoc/basicdoc.htm.

${ }^{13}$ For a listing of concluded and pending cases before ICSID, see The World Bank Group, International Centre for Settlement of Investment Disputes: ICSID Cases, http://www.worldbank.org/icsid/cases/cases.htm (last visited Nov. 9, 2007).

${ }_{14}$ Gabriel Bottini, Counsel, Office of the Attorney Gen., Republic of Arg., Issues of Jurisdiction and Merits Arising from the Argentine Litigation at ICSID, Lecture at the University of Pennsylvania Journal of International Economic Law Symposium: International Investment and Transnational Litigation:

Challenges of Growing and Expanding Investor State Disputes (Feb. 2, 2007).

${ }_{15}$ Wailin Wong, Argentina Treasury Attorney: World Bank Claims Could Reach $\$ 80$ Billion, Dow Jones INT'L NEWS, Jan. 21. 2005.

${ }^{16}$ See LG\&E v. Argentina Republic, Respondent's Memorial on the Merits. 
that which Argentina faced in 2001 and 2002 have a legal right to take actions that could harm investors and that would in ordinary circumstances violate BIT obligations. In an ever more globalized world in which exceptional circumstances such as financial crises, terrorist threats, and public health emergencies - are all too common, the ability of states to craft viable policy responses becomes ever more critical. In that context, the Argentine ICSID cases test the extent of state freedom to craft critical policy choices and the reach of investor protection under BITs and customary law in the face of exceptional, but far from uncommon, emergencies.

Argentina's first legal response has been to invoke a long-dormant treaty clause in the BITs under which investors brought their claims against Argentina and that appeared perfectly tailored to deal with just such a situation. ${ }^{17}$ Argentina's BITs with the United States, Germany, and the Belgian-Luxembourg Economic Union (BLEU) each contain a non-precluded measures (NPM) provision that limits the applicability of investor protections under the BIT in exceptional circumstances. These NPM clauses allow states to take actions otherwise inconsistent with the treaty when, for example, the actions are necessary for the protection of essential security, the maintenance of public order, or to respond to a public health emergency. ${ }^{18}$ NPM provisions effectively "permit host-state impairment of covered investment” and, in turn, weaken the BIT “as an instrument for regulating host-state governments."19 As long as the host-state's actions are taken in pursuit of one of the permissible objectives specified in the NPM clause, acts otherwise prohibited by the treaty do not constitute breaches of the treaty and states should face no liability under the BIT. The lawyers in Argentina’s Procuración del Tesoro de la Nación have argued that the economic collapse of 2001-2002 triggered the NPM clauses of many of its BITs and thereby relieved the state of liability and any duty to compensate investors. $^{20}$

A few examples of NPM clauses offer an overview of their form and legal implications for state freedom of action in response to extraordinary crises such as the Argentine

17 See CMS Gas Transmission Co. v. Argentine Republic, ICSID Case No. ARB/01/8, Award, ๆ甲 332-55 (May 12, 2005) [hereinafter CMS Award], available at http://www.worldbank.org/icsid/cases/CMS_Award.pdf.

${ }_{18}$ See, e.g., Treaty Concerning the Reciprocal Encouragement and Protection of Investment, U.S.-Arg., art. XI, Nov. 14, 1991, S. TREATY DoC. No. 103-2 (1993) [hereinafter U.S.-Argentina BIT].

19 Kenneth J. Vandevelde, Of Politics and Markets: The Shifting Ideology of the BITs, 11 INT'L TAX \& Bus. LAW. 159, 170 (1993).

20 For one such clause, see, for example, U.S.-Argentina BIT, supra note 18, art. XI. 
financial collapse. The first U.S. BIT, signed with Panama in 1982, stipulates in Article X that "[t]his treaty shall not preclude the application by either Party of any and all measures necessary for the maintenance of public order, the fulfillment of its obligations with respect to the maintenance or restoration of international peace and security, or the protection of its own essential security interests." ${ }^{21}$ Over the years, the United States has developed new versions of its Model BIT and, hence, variations in the form and structure of the NPM clause have appeared over time. One of the more notable modifications occurred in the late 1990s when the United States clarified its position on the self-judging nature of the NPM clauses in its BITs by including explicit language to that effect, now stating that a party was not precluded from taking any measures that "it considers necessary" for the protection of the stated permissible objectives. The NPM clause in the U.S.-Argentina BIT, drafted before this clarification of the self-judging nature of the treaty, provides: "[ $[$ ]his treaty shall not preclude the application by either Party of any and all measures necessary for the maintenance of public order, the fulfillment of its obligations with respect to the maintenance or restoration of international peace and security, or the protection of its own essential security interests."22

NPM clauses, such as that found in the U.S.-Argentina BIT, contain three basic elements. First, they provide for a nexus requirement. NPM clauses require that measures taken by a state that would otherwise deviate from a treaty obligation must be sufficiently related to the permissible objectives specified in the clause. This relationship is termed the "nexus requirement." One widely used phrasing of the nexus requirement found, for example, in the U.S.-Argentina BIT, requires that for measures to be covered by the clause they have to be "necessary" for the attainment of one of the specified permissible objectives. ${ }^{23}$ Second, NPM clauses specify their scope of applicability, in that they either apply to an entire BIT or can be written in a more limited form so that they apply only to a subset of the treaty's substantive provisions. The NPM clauses in U.S. BITs provide

\footnotetext{
21 Treaty Concerning the Treatment and Protection of Investments, U.S.-Pan., art. X(1), Oct. 27, 1982, 21 I.L.M. 1227 [hereinafter U.S.-Panama BIT]. A subsequent protocol amending the dispute settlement provisions of the original treaty was signed on June 1, 2000; see Protocol Amending Investment Treaty with Panama, U.S.-Pan., June 1, 2000, S. Treaty Doc. 106-46 (2000), available at http://www.unctad.org/sections/dite/iia/docs/bits/us_panama_2000.pdf.

22 U.S.-Argentina BIT, supra note 18, art. XI..

23 The NPM clauses in the U.S. BITs consistently use the "necessary for" wording. See, e.g., Treaty Concerning the Encouragement and Reciprocal Protection of Investments, U.S.-Mozam., art. XIV, Dec. 1, 1998, S. TREATY Doc. No. 106-31 (2000) [hereinafter U.S.-Mozambique BIT].
} 
that "[t]his Treaty shall not preclude" ${ }^{24}$ the application of the subsequently specified measures. As a result, the successful invocation of the NPM clause precludes the existence of a violation with respect to any and all substantive treaty provisions. In contrast, NPM clauses of a more limited scope, such as those found in German BITs, apply only to certain substantive clauses of the BIT, for example the guarantee of no "treatment less favourable." Finally, NPM clauses establish a list of permissible objectives, toward which a state's actions must be directed if they are to be covered by the exception provided for by the NPM clause. Permissible objectives in BIT NPM clauses include security, international peace and security, public order, public health, and public morality, among others. The U.S.-Argentina BIT, for example, specifies three permissible objectives: essential security, public order, and international peace and security.

Despite the fact that NPM clauses are, in fact, relatively widespread in BIT agreements and occur in most, if not all, BITs of the U.S., Germany, India, Canada and the BelgianLuxembourg Union, the Argentine cases present the first test of such cases in investorstate arbitration. ${ }^{25}$ In each of the cases arising under the U.S.-Argentina BIT, Argentina has argued that its actions in response to the financial crisis of 2001-2002 were justified as measures necessary to protect essential security and public order and that, because those actions fell within the provisions of the NPM clause, they did not violate the substantive protections accorded investors under the U.S.-Argentina BIT. As a result, Argentina has claimed that no internationally wrongful acts were committed and no state liability should attach.

In arguing that the NPM clause of the U.S.-Argentina BIT precludes Argentina's liability under the treaty, Argentina has asserted that the NPM clause should be interpreted as self-judging. Although the U.S.-Argentina BIT did not include expressly self-judging terms such as which it considers necessary, found in later U.S.-BITs, Argentina has relied on a mutual understanding of the term evidenced in the treaty's

${ }^{24}$ See, e.g., U.S.-Panama BIT, supra note 21 (emphasis added); U.S.-Mozambique BIT, supra note 23 (emphasis added).

${ }^{25}$ Similar clauses can also be fond in a number of Friendship, Commerce and Navigation Treaties and have been considered in two cases before the International Court of Justice. See Military and Paramilitary Activities in and Against Nicaragua (Nicar. v. U.S.), 1986 I.C.J. 14, 15 (June 27) [hereinafter Nicaragua Judgment (Merits)]; see also Oil Platforms (Iran v. U.S.), Preliminary Objection, 1996 I.C.J. 803, 811 (Dec. 12). 
context and travaux preparatoires from a consistent U.S. practice that such NPM clauses are understood as self-judging. ${ }^{26}$ In the alternative, Argentina has asserted that, even if the NPM clause in the U.S.-Argentina BIT is not found to be self-judging, the terms of the clause were satisfied by the situation in Argentina in late 2001 and 2002.

In addition to the treaty-based defense provided by the NPM clauses in its BITs, Argentina has also invoked the doctrine of necessity in customary international law to preclude liability for harms to investors. The customary defense of necessity provides that a state may not be liable for actions taken to "safeguard an essential interest against a grave and imminent peril."27 According to the International Law Commission (ILC) Draft Articles on the Responsibility of States for Internationally Wrongful Acts (Draft Articles):

1. Necessity may not be invoked by a State as a ground for precluding the wrongfulness of an act not in conformity with an international obligation of that State unless the act: (a) Is the only way for the State to safeguard an essential interest against a grave and imminent peril; and $(b)$ Does not seriously impair an essential interest of the State or States towards which the obligation exists, or of the international community as a whole. 2. In any case, necessity may not be invoked by a State as a ground for precluding wrongfulness if: (a) The international obligation in question excludes the possibility of invoking necessity; or $(b)$ The State has contributed to the situation of necessity. ${ }^{28}$

A successful invocation of the necessity defense precludes the wrongfulness of a state's actions and thereby allows the state to possibly avoid both responsibility and liability. As the Draft Articles explain, the defense of necessity is a secondary rule of customary international law that governs "the circumstances in which the wrongfulness of conduct under international law may be precluded.”29 Argentina has argued that the financial crisis of 2001 and 2002 impaired the country's essential interests and that the

\footnotetext{
${ }^{26}$ For a more detailed discussion of the self-judging nature of U.S. BITs, see William W. Burke-White \& Andreas von Staden, Investment Protection in Extraordinary Times: The Interpretation and Application of Non-Precluded Measures Provisions in Bilateral Investment Treaties, 48 VIRGINIA JOURNAL OF INTERNATIONAL LAW 307 (2008).

27 See Int'l Law Comm'n, Draft Articles on the Responsibility of States for Internationally Wrongful Acts with Commentaries, art. 25, U.N. Doc. A/56/10 (2001) [hereinafter ILC Draft Articles], available at http://untreaty.un.org/ilc/texts/instruments/english/commentaries/9_6_2001.pdf. ("Necessity may not be invoked by a State as a ground for precluding the wrongfulness of an act not in conformity with an international obligation of that State unless the act: $(a)$ Is the only way for the State to safeguard an essential interest against a grave and imminent peril; and (b) Does not seriously impair an essential interest of the State or States towards which the obligation exists, or of the international community as a whole.”). See also Gabcikovo-Nagymaros Project (Hung. v. Slovk.), 1997 I.C.J. 7, 39 (Sept. 25).

${ }^{28}$ See ILC Draft Articles, supra note 27, art. 24(14).

${ }^{29}$ See Id.
} 
various legislative measures Argentina took in response thereto where the only available response to that crisis. As a result, Argentina has asserted that the criteria for customary law defense of necessity were met, precluding the wrongfulness of its actions independently from its argument with respect to the treaty-based NPM exception.

Argentina's plea of necessity under customary law represents the first modern necessity claim in investor-state arbitration. While the International Court of Justice recognized the validity of the necessity defense in the Gabcikovo-Nagymaros Projects Case, the Court found the defense inapplicable in the case as Hungary was deemed to have other means available to address the environmental threats to its essential interests. ${ }^{30}$ In its submissions to ICSID, Argentina has also relied on a number of earlier cases before arbitral tribunals and the Permanent Court of International Justice, in which necessity was claimed on the basis of a state's financial problems and in which tribunals applied a more lenient standard than did the ICJ in Gabcikovo, including Société Commerciale de Belgique $^{31}$ and the Serbian Loans Case. ${ }^{32}$

The four arbitrations against Argentina decided thus far and the remaining claims still pending provide a critical test of both the interpretation and applicability of NPM clauses and the availability of the customary law defense of necessity in response to a major economic crisis. In so doing, these cases test the flexibility available to states to craft policy responses to emergencies and the scope of investor protections in such circumstances.

IV. THE JURISPRUDENCE OF THE ICSID TRIBUNALS

The four awards handed down in the Argentine cases as of early 2008 consider both the NPM exception and the necessity defense advanced by Argentina and reach

\footnotetext{
${ }^{30}$ See Gabčikovo-Nagymaros Project, 1997 I.C.J. at 40, 42. The Court noted "that, even supposing, as Hungary maintained, that the construction and operation of the dam would have created serious risks, Hungary had means available to it, other than the suspension and abandonment of the works, of responding to that situation. It could for example have proceeded regularly to discharge gravel into the river downstream of the dam." Id. at 42.

${ }^{31}$ Société Commerciale de Belgique, 1939, P.C.I.J., Series A/B, No. 78, p. 160; Secretariat Survey, ๆ. 288.

${ }^{32}$ Case Concerning Certain Serbian Loans, 1929, P.C.I.J., Series A, No. 20; Secretariat Survey, ףs. 263268. See also International Law Commission, Commentaries on the Draft Articles on the Responsibility of States for Internationally Wrongful Acts, at Art 25, p. 141, fn. 410.
} 
contradictory and, at times, legally questionable conclusions. ${ }^{33}$ Whereas the Tribunals in the cases of CMS v. Argentina, Enron v. Argentina and Sempra v. Argentina found both the NPM clause and the necessity defense inapplicable, the Tribunal in $L G \& E v$. Argentina found the NPM clause properly invoked and the necessity defense potentially applicable to Argentina. ${ }^{34}$

Significantly, however, both the jurisprudence and legal reasoning of these ICSID Tribunals is often problematic. Not only do these Tribunals essentially ignore the treatybased NPM exception and restrict the necessity defense, the findings of at least three of the Tribunals appear to overlook the basic bargain between investor protection and state freedom of action inherent in a BIT and, thereby, limit the state's ability to respond to exceptional situations, such as financial crises, in ways that that may threaten the longterm willingness of states to participate in investor-state arbitration and, perhaps, the legitimacy of that system itself.

\section{The ICSID Tribunals and Non-Precluded Measures Provisions}

While the four Tribunals that have issued awards in the Argentina cases reach different substantive outcomes and their decisions take distinct approaches to the function of NPM clauses, they agree on at least two critical points. First, the Tribunals interpret the essential security and public order provisions of the U.S.-Argentina BIT broadly enough to encompass economic emergencies, such as the financial crisis that enveloped Argentina in late 2001 and 2002.

\footnotetext{
33 The four cases decided to date are: CMS, supra note 17; LG\&E Energy Corp. v. Argentine Republic, ICSID Case No. Arb/02/1, Decision on Liability (Oct. 3, 2006), ๆף 226, 266 [hereinafter LG\&E Decision on Liability], available at http://www.worldbank.org/icsid/cases/pdf/09_LGE_Liability_e.pdf., 9 212; Enron Award, supra note 35, $₫$ 337.; ${ }^{33}$. Enron Corp. Ponderosa Asset, L.P. v. Argentine Republic, ICSID Case No. Arb/01/3, Award (May 22, 2007) [hereinafter Enron Award], available at http://ita.law.uvic.ca/documents/Enron-Award.pdf at II373; and Sempra Energy Int'l v. Argentine Republic, ICSID Case No. Arb/02/16, Award, ๆ 391 (Sept. 28, 2007) [hereinafter Sempra Award], available at http://www.investmentclaims.com/decisions/Sempra_Energy-Award.pdf, at I 388. The CMS case is presently subject to annulment proceedings. The arbitral panel in the $C M S$ case consisted of Francisco Orrego Vicuna (President), Marc Lalonde and Francisco Rezek. The $L G \& E$ panel consisted of Tatiana de Maekelt (President), Francisco Rezek, and Albert Jan van den Berg. The Enron panel consisted of Francisco Orrego Vicuna, Albert Jan van den Berg and Pierre Yves Tschanz.

34 See Enron Award, supra note 33, ๆף 226-66 (“Argentina is exempt of responsibility, and accordingly, the Claimants should bear the consequences of the measures taken by the host State....”); CMS Award, supra note 17, 9 387. The divergent decisions raise the problem of an arbitral system without meaningful appellate authority and no means of resolving different outcomes based on nearly identical facts.
} 
A second area of agreement between the Tribunals is their interpretation of the NPM clause in the U.S.-Argentina BIT as not self-judging. ${ }^{35}$ While the language of the NPM clause in the U.S.-Argentina BIT is not explicitly self-judging, Argentina has argued that it should be interpreted as self-judging, again based on long-standing practice of the United States. The Tribunals unanimously reject this claim and, therefore, apply a substantive review to Argentina's invocation of the clause rather than a less strict good faith test. $^{36}$

Yet, the Tribunals justify this common approach to the NPM clause as non-selfjudging on very different grounds. For the $C M S$ Tribunal, the non-self-judging character of the U.S.-Argentina NPM clause is based on a textual comparison of the NPM clause in the treaty with other instruments, such as GATT, that are explicitly self-judging and the ICJ's treatment of similar language in the Nicaragua case. ${ }^{37}$ In contrast, the determinations by the $L G \& E$ Tribunal and the Enron Tribunal are, in part, based on supposed consideration of the parties' understandings at the time the treaty was concluded. In the words of the $L G \& E$ Tribunal: “[b]ased on the evidence before the Tribunal regarding the understanding of the Parties in 1991 at the time the Treaty was signed, the Tribunal decides and concludes that the provision is not self-judging." ${ }^{38}$ In reaching this conclusion, the LG\&E Tribunal recognizes that the "language of the BIT does not specify who should decide what constitutes essential security measures-either Argentina itself, subject to a review under a good faith standard, or the Tribunal," and looks to both the background materials and broader context of the treaty negotiations. ${ }^{39}$ Despite the four Tribunals' agreement on the non-self-judging nature of the NPM clause, only the Sempra Tribunal gives serious consideration to the weighty evidence of the common intent of the United States and Argentina that the clause should be self-

\footnotetext{
${ }^{35}$ Enron Award, supra note 33, ๆ 373; Sempra Award, supra note 33, at \ 388, 391.

${ }^{36}$ The author has argued elsewhere that, due to the extensive US practice interpreting NPM clauses as selfjudging, the clause contained in the U.S.-Argentina BIT should be interpreted as self-judging and subject only to good faith review by an arbitral tribunal and not a full substantive review of the state's policies. See Burke-White \& von Staden, supra note 26.

37 CMS Award, supra note 17, ๆ 371.

38 LG\&E Decision on Liability, supra note 33, at 9 ๆ 226, 266; Enron Award, supra note 33, at 9337.

$39 L G \& E$ Decision on Liability, supra note 33, 1212 . For example, the tribunal considers when the U.S. policy with respect to self-judging NPM clauses became explicit and finds that did not occur until 1992, after the U.S.-Argentina BIT was signed. $I d$. 1 213. Despite the agreement of the two tribunals that the NPM clause in the U.S.-Argentina BIT is not self-judging, there is reason to question both tribunals' decisions. As noted above, prior to the conclusion of the U.S.-Argentina BIT, the United States had asserted a self-judging interpretation of the NPM clause in its BITs.
} 
judging. ${ }^{40}$ Yet, even the Sempra Tribunal, notably composed of two arbitrators who also served in the $C M S$ case, dismisses the relevance of that evidence and also concludes that the NPM clause is non-self-judging. ${ }^{41}$

Despite agreement on the applicability of the NPM clause to economic emergencies and its non-self-judging nature, the four awards differ on a number of significant issues. A first key difference among the decisions is their approach to the relationship between the NPM clause in the treaty and the customary law defense of necessity. ${ }^{42}$ The $C M S$ Tribunal, the Enron Tribunal, and the Sempra Tribunal effectively read the requirements of the customary international law defense of necessity into the NPM clause of the treaty, testing Argentina's invocation of the NPM clause against the basic requirements of the necessity defense in customary international law. ${ }^{43}$ The Enron Tribunal observes: "because there is no specific guidance" as to the interpretation of the NPM clause "under the treaty...[it is] necessary to rely on the requirements of the state of necessity under customary law." ${ }^{44}$ Likewise, the CMS Tribunal begins its analysis of Article XI with explicit reference to "Article 25 of the Articles on State Responsibility" which addresses the necessity defense in customary law and asks whether "the plea of necessity would...be precluded. ${ }^{, 45}$ In contrast, the $L G \& E$ Tribunal considers Article XI of the BIT and the state of necessity in customary international law independently and does not impose the requirements of customary international law on Argentina's invocation of the treaty-based NPM clause. The $L G \& E$ Tribunal notes:

The concept of excusing a State for the responsibility for violation of its international obligations during what is called a "state of necessity" or "state of emergency" also exists in international law. While the Tribunal considers that the protections afforded by Article XI have been triggered in this case, and are

40 See Enron Award, supra note 33, ๆ 337; LG\&E Decision on Liability, supra note 33, ๆ 212; CMS Award, supra note 17, 1371.

${ }^{41}$ See Sempra Award, supra note 33, at 9ף 382-88.

${ }^{42}$ For a discussion of the treatment of the state of necessity in the two cases, see August Reinisch, Necessity in International Arbitration - An Unnecessary Split of Opinions in Recent ICSID Cases? Comments on CMS v. Argentina and LG\&E v. Argentina, 3 TransNaTI'L DisP. MGMT. (2006); Stephan W. Schill, International Investment Law and the Host State's Power to Handle Economic Crises, $24 \mathrm{~J}$. INT'L ARB. 265, 277-84 (2007).

${ }^{43}$ CMS Award, supra note 17, 935 (asking if, "in the context of Article 25 of the Articles on State Responsibility [the necessity defense], the act in question does not seriously impair an essential interest of the State or States towards which the obligation exists”); see also Sempra Award, supra note 33, ๆ 376 ("The Treaty provision is inseparable from the customary law standard.").

44 Enron Award, supra note 33, 9333.

${ }^{45}$ CMS Award, supra note 17, ๆฯ 353, 358. The CMS tribunal did analyze Article XI of the treaty independently of the customary defense of necessity, but read the customary law standards for invoking necessity back into its analysis of the NPM clause. Id. ๆศ 353-358. 
sufficient to excuse Argentina's liability, the Tribunal recognizes that satisfaction of the state of necessity standard as it exists in international law (reflected in Article 25 of the ILC's Draft Articles on State Responsibility) supports the Tribunal's conclusion. ${ }^{46}$

Although the fact that the requirements of the customary defense of necessity have been satisfied may support the $L G \& E$ Tribunal's findings, the successful invocation of the NPM clause ought to be based on a separate test and distinct evidence, independent from the customary defense of necessity itself. For the $L G \& E$ Tribunal, the NPM clause is a separate risk allocation device and an explicit part of the bargain in the U.S.Argentina BIT, providing the states parties greater protections than would have been available in customary law. For the CMS, Enron, and Sempra Tribunals, in contrast, the NPM clause appears to be merely a textual restatement of the pre-existing customary defense of necessity that has no independent legal impact.

As both a legal and policy matter, the approach taken by the $L G \& E$ Tribunal is far more appropriate. Legally, reading the customary defense of necessity into the NPM clause both violates the Vienna Convention rule of lex specialis and the canonical rule that each treaty provision must be given effect. As a matter of policy, the incorporation of the necessity defense into the NPM clause fails to recognize the actual understanding of the U.S. and Argentina, whereby, in exchange for granting investors greater protections than would have been available in customary law, the states also sought to preserve for themselves greater freedom of action through the NPM clause than would have been available in customary international law.

A second area of significant disagreement among the four Tribunals is the level of deference they accord to Argentina's invocation of the NPM clause. While all the Tribunals agree the clause is not self-judging, the CMS, Enron, and Sempra Tribunals apply a far more rigorous standard to the nexus requirement under the NPM clause, importing the customary law requirements of necessity and requiring Argentina to show that the actions it took were the only ones available to the government to respond to the crisis. Although the Sempra Tribunal recognizes that "it is not the task of the tribunal to substitute its view for the government's choices," its interpretation of the "only available means” requirement essentially removes all policy responses from the NPM clause

${ }^{46} L G \& E$ Decision on Liability, supra note 33, ๆ 245. 
exception simply by finding that there were more than one possible response to the crisis. ${ }^{47}$ In contrast, the $L G \& E$ Tribunal takes an approach somewhat closer to the margin of appreciation doctrine in European human rights law, according to which an international tribunal will give discretion to the state itself to craft its policies within a margin of international supervision. The $L G \& E$ Tribunal suggests, for example, that were it "to conclude that the provision is self-judging, Argentina's determination would be subject to a good faith review anyway, which does not significantly differ from the substantive analysis presented here." ${ }^{\text {"48 }}$ In essence, then, the $L G \& E$ Tribunal reduces the level of scrutiny of Argentina's invocation of Article XI down to something close to a good faith review and appears to afford Argentina a margin of appreciation in which to make its own determinations of the appropriate responses to the crisis. For example, the $L G \& E$ Tribunal found:

Certainly, the conditions in Argentina in December 2001 called for immediate, decisive action to restore civil order and stop the economic decline....Article XI refers to situations in which a State has no choice but to act. A State may have several responses at its disposal to maintain public order or protect its essential security interests. ${ }^{49}$

The LG\&E approach recognizes the subjective nature of certain permissible objectives under the BIT and finds that states, rather than ICSID Tribunals, are often in the best position to craft appropriate policy responses to emergency situations.

A third area of substantive disagreement among the Tribunals is the question of compensation. While the CMS Tribunal did not find either the requirements of necessity in customary international law or the standards of the NPM clause met, it suggested that neither provision would, even if applicable, excuse the state invoking the clause of liability and the duty to pay compensation. ${ }^{50}$ In contrast, the $L G \& E$ Tribunal opined that “Article XI establishes the state of necessity as a ground for exclusion from wrongfulness of an act of the State, and therefore, the State is exempted from liability." 51 As a

\footnotetext{
47 Sempra Award, supra note 33, ๆ 350 -51. This approach fails to give the government any policy flexibility and does not recognize that some policy options may be more or less effective in responding to the crisis.

${ }^{48} L G \& E$ Decision on Liability, supra note 33, ๆ 214.

49 Id. ๆ $238-39$.

50 The CMS Tribunal observed, for example, that "the plea of state of necessity may preclude the wrongfulness of an act, but it does not exclude the duty to compensate the owner of the right which had been sacrificed." Hence, "in the absence of agreement between the parties the duty of the tribunal in these cases is to determine the compensation due.” CMS Award, supra note 17, ๆף 388, 394.

$51 L G \& E$ Decision on Liability, supra note 33, ๆ 261.
} 
consequence, the $L G \& E$ Tribunal found that Argentina was not liable for damages to investors during the period of emergency. ${ }^{52}$ Given that the very purpose of the NPM clause was to guarantee states greater freedom of action in the face of extraordinary circumstances in exchange for enhanced protections for investors, the approach taken by the $L G \& E$ Tribunal appears to better reflect the bargain inherent in the NPM clause of the U.S.-Argentina BIT. If such clauses were not intended to prevent liability, they would not in fact serve the purpose of guaranteeing greater freedom of action to states in cases of emergency as such states would remain liable notwithstanding the NPM clause.

Despite the $L G \& E$ Tribunal's more favorable stance toward Argentina, the awards in the CMS, Enron, and Sempra arbitrations severely limit the applicability of the NPM clause in the U.S.-Argentina BIT. By requiring Argentina's invocation of the NPM clause to meet the requirements of the necessity defense in customary international law and providing very little deference to Argentina's policy choices in response to the financial crisis, the these three Tribunals make it extremely difficult for any state to invoke the NPM clause of a BIT instrument, thereby narrowing the state's potential policy responses in a crisis situation and ensuring that, notwithstanding the inclusion of an NPM clause in the BIT, the state remains liable to investors for harms caused by policy responses to such a crisis.

The jurisprudence of the ICSID Tribunals in the Argentina cases is particularly problematic for two reasons. First, the legal reasoning in these awards is often deeply flawed. Specifically, by conflating the NPM clause with the customary defense of necessity, the Tribunals violate the principle of effectiveness in treaty interpretation ( $u t$ res magis valeat quam pereat). As the WTO Appellate body found in the U.S.-Gasoline case, “[o]ne of the corollaries of the 'general rule of interpretation' in the Vienna Convention is that interpretation must give meaning and effect to all the terms of a treaty. An interpreter is not free to adopt a reading that would result in reducing whole clauses or paragraphs of a treaty to redundancy or inutility., ${ }^{, 3}$ Reading an NPM clause as equivalent

\footnotetext{
${ }^{52}$ Id. I 266 ("Based on the analysis of the state of necessity, the Tribunal concludes that, first, said state started on December 1, 2001 and ended on April 26, 2003; second, during that period Argentina is exempt of responsibility, and accordingly, the Claimants should bear the consequences of the measures taken by the host State.”).

53 Appellate Body Report, United States-Standards for Reformulated and Conventional Gasoline, WT/DS2/AB/R (Apr. 29, 1996) [hereinafter United States—Standards for Reformulated and Conventional Gasoline]. Similarly, Professor Fitzmaurice observes, "texts are to be presumed to have been intended to
} 
to the customary defense of necessity would render the clause pointless because the customary defense of necessity would be available to states irrespective of the inclusion of the NPM clause in a BIT. In order to satisfy the principle of effectiveness in treaty interpretation, NPM clauses must be read as distinct rules that states create in their treaty relationships, independent of the necessity defense in customary international law, and establishing a separate grounds for precluding state liability.

A second fundamental problem with the jurisprudence of the Tribunals in the Argentine cases is that it fails to do justice to the intent of the parties as expressed in the clear language of the U.S.-Argentina BIT. As the drafting history of the U.S-Argentina BIT indicates, the U.S. and Argentina included an NPM provision precisely because they sought to secure for themselves greater policy flexibility in response to exceptional circumstances than would have been ordinarily available under customary international law. ${ }^{54}$ By failing to recognize the scope of the NPM clause as intended by the parties and drafted into the BIT, the Tribunals foreclose the very policy options that the U.S. and Argentina sought to preserve for themselves in extreme situations and provide investors with greater protections than the states intended to confer on them. The result is not just poor law, but also a direct challenge to states parties to BIT instruments with NPM clauses that forces them to ask whether ICSID Tribunals will, in fact, interpret BITs in a balanced way that conforms to the intent of the drafters as memorialized in a BIT. To the degree that such tribunals overstep the intent of the states parties and the plain language of the BIT itself, they may well chill states from entering into further BIT instruments and subjecting themselves to ICSID jurisdiction.

\section{The ICSID Tribunals and The Customary Defense of Necessity}

have a definite force and effect, and should be interpreted so as to have such force and effect rather than so as not to have it and so as to have the fullest value and effect consistent with their wording." G. G. Fitzmaurice, The Law and Procedure of the International Court of Justice: Treaty Interpretation and Certain Other Treaty Points, 28 BRIT. Y.B. INT'L L. 1, 8 (1951); see also H. Lauterpacht, Restrictive Interpretation and the Principle of Effectiveness in the Interpretation of Treaties, 26 BRIT. Y.B. INT'L L. 48 (1949).

${ }^{54}$ For a discussion of the drafting history of the NPM clause and the US BIT program more generally, see Burke-White \& von Staden, supra note 26. 
In addition to asserting the exception to the substantive protections of the BIT provided for by the NPM clause, Argentina has also invoked the separate defense of necessity under customary international law in each of the ICSID arbitrations against it. Despite the fact that the four Tribunals that have issued awards in the Argentine cases have improperly conflated the treaty-based NPM clause with the customary law defense of necessity, each Tribunal does offer an opinion on the applicability of the necessity defense to the Argentine financial crisis. Although the $L G \& E$ Tribunal found that the necessity defense might be available to Argentina, the CMS, Enron and Sempra Tribunals all held the necessity defense inapplicable and the wrongfulness of Argentina's actions not precluded. All four Tribunals accept the ILC's Draft Articles as the definitive interpretation of the necessity defense in customary law and apply the criteria specified in the Draft Articles to determine the applicability of the necessity defense. While the $C M S$, Enron and Sempra Tribunals suggest somewhat different standards for the invocation of necessity under customary law, all three offer such narrow interpretations of necessity so as to make the defense essentially unavailable to a state attempting to devise a policy response to a severe crisis or other emergency.

As an initial matter, the CMS, Enron, and Sempra Tribunals find that the economic crisis, which befell Argentina, was not of a sufficient magnitude to threaten Argentina's essential interests and, thereby, open the door to a necessity defense. The CMS Tribunal, for example, notes that: "The Tribunal is convinced that the crisis was indeed severe.... However, neither could it be held that wrongfulness should be precluded as a matter of course under the circumstances." ${ }^{55}$ Similarly, while acknowledging that Argentina faced a severe crisis, the Enron Tribunal opines that "the argument that such a situation compromised the very existence of the State and its independence so as to qualify as involving an essential interest of the State is not convincing." Tribunal found that the financial crisis in Argentina was sufficient to imperil an essential interest and, thereby, open the door to the necessity defense: "As evidence demonstrates, economic, financial or those interests related to the protection of the State against any danger seriously compromising its internal or external situation, are also considered

${ }^{55}$ CMS Award, supra note 17, ๆ 320.

${ }^{56}$ Enron Award, supra note 33, at $\$ 306$. 
essential interests."57

A second issue considered by all four Tribunals arises from article 25(1)(a) of the Draft Articles, according to which the defense of necessity is only available if the actions taken by the state were "the only way for the State to safeguard an essential interest against a grave and imminent peril." ${ }^{58}$ As the ILC Commentaries to the Draft Articles provide: "The plea is excluded if there are other (otherwise lawful) means available, even if they may be more costly or less convenient."59 The key question facing the four Tribunals in this regard was how to interpret the no other available means requirement. Would it be sufficient to invalidate the plea of necessity if, for example, there were some other policy choice open to Argentina or would it have to be shown that there was an equally effective policy response open to Argentina that would not have breached the substantive protections of the BIT? At its core, that is a question of how much deference to give the Argentine government's determination that its policy choice was the only or best available response to the crisis.

Again, the CMS, Enron and Sempra Tribunals offer extremely narrow interpretations of the necessity defense, essentially second-guessing Argentina's policy choices and suggesting that, because some other means was available to Argentina to respond to the crisis, the necessity defense was legally unavailable. The $C M S$ Tribunal, for example, finds that the ILC's comment "that the plea of necessity is 'excluded if there are other (otherwise lawful) means available, even if they may be more costly or less convenient,' is persuasive in assisting this Tribunal in concluding that the measures adopted were not the only steps available." ${ }^{\circ 0}$ Similarly, the Enron Tribunal notes: “A rather sad world comparative experience in the handling of economic crises, shows that there are always many approaches to address and correct such critical events, and it is difficult to justify that none of them were available in the Argentine case."61 The CMS, Enron and Sempra Tribunals all fail to suggest alternative courses of action Argentina could have followed ${ }^{62}$

\footnotetext{
${ }^{57} L G \& E$ Decision on Liability, supra note 33, at 9251.

${ }^{58}$ International Law Commission, Draft Articles on the Responsibility of States for Internationally Wrongful Acts, supra note 28, at art. 25.

${ }^{59}$ ILC Commentaries, supra note 28, art. 25, pg 203, ๆ16.

${ }^{60}$ CMS Award, supra note 17, at 9324.

${ }^{61}$ Enron Award, supra note 33, at $\mathbf{9 3 0 8}$. See also Sempra Award, supra note 33, at 9350 (providing a word-for-word identical discussion as the CMS Tribunal).

62 The Sempra Tribunal merely notes that "it is not the task of the Tribunal to substitute its view for the
} 
or to consider the counterfactual argument of the results such alternative policies might have entailed for both the state and investors. The three Tribunals simply assert that if any alternative policy choice is available-regardless of its likely effectiveness-the necessity defense is unavailable. Since states always face a range of policy choices in response to any issue, whichever policy a state chooses is, by definition, not the only available response to the crisis. The three Tribunals thus give no deference whatsoever to Argentina's policy choices and, essentially, vitiate the necessity defense as a matter of law.

In contrast, the $L G \& E$ Tribunal gives considerable deference to Argentina's own policy choices in response to the crisis, recognizing that an ad hoc arbitral tribunal is poorly positioned to second-guess the policies of the government. The $L G \& E$ Tribunal observes: "In this circumstance, an economic recovery package was the only means to respond to the crisis. Although there may have been a number of ways to draft the economic recovery plan, the evidence before the Tribunal demonstrates that an acrossthe-board response was necessary, and the tariffs on public utilities had to be addressed."63 The $L G \& E$ Tribunal does not ask if a slightly different recovery package could have been employed, but merely determines that some across-the-board recovery package was needed. It pays deference to Argentina's determination that the specific policies adopted by the country were the most appropriate in the circumstances and finds that the criteria for invocation of the necessity defense in customary law were satisfied. This approach is far more appropriate in that it leaves open the necessity defense as long as some other clearly available and less restrictive policy alternative would not have provided an obviously adequate response to the crisis with less harm to the interests of investors.

The final issue with respect to the invocation of the necessity defense in customary law considered by all four Tribunals is whether Argentina contributed to the situation of necessity. ${ }^{64}$ The four Tribunals ask what level of contribution by a state to a crisis would be necessary to render the necessity defense inapplicable. In the Gabcikovo-Nagymoros

Government's choice between economic options. It is instead the Tribunal's duty only to determine whether the choice made was the only one available, and this does not appear to have been the case." Sempra Award, supra note 33, at 9351.

${ }^{63}$ LGE Decision on Liability, supra note 33, at 9257.

${ }^{64}$ ILC Draft Articles, supra note 28, at 25. 
Projects Case, for example, the ICJ found the plea of necessity inapplicable because Hungary had "helped, by act or omission to bring" into being the situation of necessity. ${ }^{65}$ According to the ILC Commentaries, "the contribution to the situation of necessity must be sufficiently substantial and not merely incidental or peripheral."66

The CMS, Enron, and Sempra Tribunals all found that any contribution by Argentina whatsoever, including long range economic planning, was sufficient to invalidate the plea of necessity. In the words of the Enron Tribunal, "Although each party claims that the factors precipitating the crisis were either endogenous or exogenous, the truth seems to be somewhere in between with both kind of factors having intervened... his means that to an extent there has been a substantial contribution of the State to the situation of necessity and that it cannot be claimed that the burden falls entirely on exogenous factors." ${ }^{27}$ Similarly, the CMS Tribunal notes: "The crisis was not of the making of one particular administration and found its roots in the earlier crisis of the 1980s and evolving governmental policies of the 1990s that reached a zenith in 2002 and thereafter. Therefore, the Tribunal observes that government policies and their shortcomings significantly contributed to the crisis and the emergency and while exogenous factors did fuel additional difficulties, they do not exempt the Respondent from its responsibility in the matter." ${ }^{68}$ As a result, these three Tribunals determined that the necessity defense was unavailable to Argentina because the state had contributed to the crisis.

Again, the $L G \& E$ Tribunal took a very different approach to the level of contribution necessary to exclude the plea of necessity, finding that even if Argentina had contributed to the underlying economic crisis, that contribution was neither significant nor intentional. In this respect, the $L G \& E$ Tribunal found that "in the first place, Claimants have not proved that Argentina has contributed to cause the severe crisis faced by the country; secondly, the attitude adopted by the Argentine Government has shown a desire to slow down by all the means available the severity of the crisis." ${ }^{39}$ The $L G \& E$ Tribunal thus left the plea of necessity open to Argentina.

With respect to the applicability of the necessity defense, there is a clear split in the

\footnotetext{
${ }^{65}$ I.C.J. Reports 1997i, p. 7, at p. 46, ๆ 57.

${ }^{66}$ ILC Commentaries, supra note 28, at art 25, ๆ 20.

${ }^{67}$ Enron Award, supra note 33, at $₫ 312$.

${ }^{68}$ CMS Award, supra note 17 , at 9329.

${ }^{69} L G \& E$ Decision on Liability, supra note 33, at \ 256.
} 
jurisprudence of the ICSID Tribunals to date. While the CMS, Enron, and Sempra Tribunals significantly limit the availability of the necessity defense and find it unavailable to Argentina, the $L G \& E$ Tribunal offers a far more deferential analysis of the state's invocation of necessity and finds the defense to apply in the case of the Argentine financial crisis. The approach taken by the majority of the tribunals thus far is, again, problematic because the analysis used by these three Tribunals essentially renders the necessity defense a legal nullity as a state will, almost without exception, have contributed at least in some indirect way to whatever emergency it may face and such a state will also, in almost every circumstance, have more than one possible policy response to such a situation. If this majority line of jurisprudence is followed, a state responding to a any crisis, with the possible exception of a truly unforeseeable natural disaster, despite the technical availability of the necessity defense, will be unable as a matter of law to successfully invoke the defense and liability will attach to whatever policy the state may chose to respond to the crisis. Again, as with the Tribunals' flawed interpretation of the NPM clause, the result may be to chill states' willingness to enter into BIT obligations or to subject themselves to ICSID jurisdiction.

\section{The CMS ANNULment COMMitTeE RePORT AND THE ViabiLITY OF ICSID} ARBITRATION

The opinions of the four Tribunals that have issued awards in the Argentina cases to date raise serious questions as to the legitimacy and viability of the ICSID system, particularly in cases such as these in which disputes implicate fundamental questions of state policy, such as the appropriate response to a financial crisis or other emergency. The legitimacy problem arises first from the contradictory holdings of the four Tribunals. The facts in each of the four cases are identical. In each case Argentina advanced the same argument-that the actions taken in response to the crisis were necessary to protect essential security interests and maintain public order under the NPM clause and that the criteria for the invocation of the necessity defense were met. Likewise, in each case Argentina presented very similar evidence and expert testimony. Yet, the Tribunals 
reached opposite conclusions, based on different interpretations of the treaty's NPM terms and different understandings of the necessity defense in customary international law. ${ }^{70}$ The fact that four Tribunals, when confronted with the same facts, evidence, and argumentation would reach very different interpretations of the law and diametrically opposite holdings is, itself, sufficient to call into question the legitimacy and viability of the ICSID arbitral system.

The Argentine cases are, of course, not the first time that investor-state arbitrations have produced contradictory awards. The now infamous Lauder v. Czech Republic case, in which Lauder asserted breaches of BIT and contract rights based on the Czech Republic's interference with media licenses, involved two separate arbitrations, one under the U.S.-Czech BIT brought by Lauder and one under the Netherlands-Czech BIT brought by a CME, a Dutch corporation. ${ }^{71}$ The two Tribunals in those cases also reached directly opposite conclusions with respect to whether a causal link existed between the Czech Republic's actions and the harms done to Lauder. Those cases led to numerous calls in both the academic and practitioner communities for reforms to the investor-state arbitration system and, particularly, the creation of an appellate review system. ${ }^{72}$ Though no such reforms were undertaken in the wake of the Lauder cases, the recent Argentine awards raise once again the danger of inconsistent decisions and lack of appellate review in the ICSID system.

A second question of legitimacy arising from the Argentine cases relates to the composition of the Tribunals and the precedential value of ICSID awards. While the three Argentine cases that narrow the applicability of the NPM clause and restrict the necessity

\footnotetext{
70 See CMS Award, supra note 17; LG\&E Decision on Liability, supra note 33 None of these past decisions is controlling in the interpretation of an NPM clause in a future case. See Statute of the International Court of Justice art. 30, June 26, 1945, 59 Stat. 1055, T.S. 993.

${ }^{71}$ Compare Lauder v. Czech Republic, Final Award, ๆ 313 (Sept. 3, 2001), available at http://ita.law.uvic.ca/documents/LauderAward.pdf (last visited Dec. 5, 2007), with CME Czech Republic BV v. Czech Republic, Partial Award, 1575 (Sept. 13, 2001), available at http://ita.law.uvic.ca/documents/CME-2001PartialAward.pdf (last visited Mar. 5, 2005), and CME Czech Republic BV v. Czech Republic, Final Award, paras. 446-47 (Mar. 14, 2003), available at http://ita.law.uvic.ca/documents/CME-2003-Final 000.pdf (last visited Dec. 5, 2007).

${ }^{72}$ See Charles N. Brower et al., The Coming Crisis in the Global Adjudication System, 19 ARB. INT'L 415, 430-32 (2003); Susan Franck, The Legitimacy Crisis in Investment Treaty Arbitration: Privatizing Public International Law Through Inconsistent Decisions, 73 FORDHAM L. REV. 1521 (2005); Susan Franck, ICSID Institutional Reform: The Evolution of Dispute Resolution and the Role of Structural Safeguards, in INTERNATIONAL INSTITUTIONAL REFORM: PROCEEDINGS OF THE HAGUE JOINT CONFERENCE ON CONTEMPORARY ISSUES IN INTERNATIONAL LAW (Ed. Agata Fijalkowsi) (2007).
} 
defense now appear to constitute a clear majority position and are being cited as precedent by other Tribunals, the structure of the ICSID system may well unduly weight the opinions of particular arbitrators who sit in a number of similar cases. In fact, the arbitral panels in the CMS, Enron, and Sempra cases had overlapping members. Professor Francisco Orrego Vicuna served as President of all three Tribunals and Marc Lalonde sat on both the Sempra and CMS panels. The CMS and Sempra awards not surprisingly contain verbatim legal analysis of numerous issues and the sole arbitrator in Sempra who had not also sat in CMS, Sandra Morelli Rico, offered a dissenting opinion that disagreed with many of the legal conclusions of the other two arbitrators. As Charles Brower has noted, when considering such cases, "the possibility dawns that selection of the tribunal like jury selection - plays a role more dispositive and less unifying than the text of the treaty obligations."73

Of course, the desire for uniformity of jurisprudence might suggest that such overlapping panels is advantageous as it is more likely to lead to consistent outcomes. Yet, in a system such as ICSID that lacks appellate review authority, the repetition of particular arbitrators and, likely, their key holdings in numerous cases may confer greater legitimacy and precedential weight on particular lines of argument or legal conclusions. ${ }^{74}$ When panels have the same president and, particularly, when they have a decisive majority of repeat members, the likelihood that they will analyze identical facts and legal analysis differently in a second case, declines markedly. ${ }^{75}$ What appears to occur instead is that the opinion of particular repeat player arbitrators in these cases is given additional weight as they decide nearly identical cases based on the same legal and factual analysis and thereby establish repeat, even if erroneous, precedents. Without appellate review, those repeat precedents gain perhaps undue weight and authority within the system.

The third, and perhaps the most profound, question of legitimacy presented by the Argentine ICSID awards to date arises from the substantive decisions of three of the four

\footnotetext{
${ }^{73}$ Charles H. Brower II, Emerging Dilemmas in International Economic Arbitration: Mitsubishi, Investor State Arbitration, and the Law of State Immunity, 20 AM. U. INT’L L. REV. 907, 923 (2005).

${ }^{74}$ For a discussion of the value of precedent in investment treaty arbitration, see Tai-Heng Cheng, Precedent and Control in Investment Treaty Arbitration, 30 FORDHAM INT’L J. 1014 (2007).

${ }^{75}$ The Tribunal in the Sempra case did note that "While two arbitrators sitting in the present case were also members of the tribunal in the $C M S$ case the matter has been examined anew." Sempra Award, supra note 33, at 9 346. The verbatim legal analysis of many issues in the two cases makes this claim somewhat difficult to accept.
} 
Tribunals with respect to both the NPM clause and the customary defense of necessity. This majority approach drastically limits the freedom of states to respond to emergency situations through both a narrow interpretation of the NPM clause and a highly restrictive reading of the necessity defense. By limiting, or even removing the possibility, of either of these exemptions from wrongfulness and liability, despite the manifest intent of the states parties to the BIT to include an NPM provision and maintain the customary defense of necessity, the Tribunals turn the U.S.-Argentine BIT into a far stronger instrument of investor protection than the states parties to the treaty likely intended. The failure to give effect to the clear language of the BIT and to do justice to the intent of the states parties as manifested in the treaty language is, not surprisingly, causing states to rethink their commitment to guarantee investor rights through BITs and allow direct investor-state arbitration before ICSID. After all, BITs represent an explicit bargain between the benefits of increased investment flows that follow from legalized investor protections and the need for states to preserve policy flexibility in ways that could impair investor interests. If ICSID Tribunals fail to recognize or accept the nature of that bargain underlying many BITs, states may be far less willing to accept direct investor-state arbitrations that appear to favor, or even expand, investor rights.

These three legitimacy concerns alone have prompted leading scholars and practitioners to question the viability and legitimacy of investor-state arbitration. More significantly, they have led some states to withdraw from the ICSD system so as to minimize the potential for investor-state arbitrations based on their BIT obligations in a system which they perceive to lack legitimacy. In May 2007, for example, Bolivia notified the World Bank that it was withdrawing from the ICSID Convention and Bolivian President Evo Morales urged his Latin American counterparts to do the same. ${ }^{76}$ Other states such as Venezuela and Ecuador have noted the desire to limit ICSID jurisdiction and minimize potential BIT liability. ${ }^{77}$ As states reconsider their commitment to ICSID in light of these legitimacy challenges, the viability of investor-state arbitration in its present form is called into question.

\footnotetext{
${ }^{76}$ See Bolivia Notifies World Bank of Withdrawal from ICSID, Pursues BIT Revisions, International Institute for Sustainable Development, Investment Treaty News, 7 May 2007, available at http://www.bilaterals.org/article.php3?id_article=8221.

${ }^{77}$ See Treaty Developments Related to Bolivia, Ecuador, and Venezuela, White \& Case International Disputes Quarterly, Fall 2007, available at http://www.whitecase.com/idq/fall_2007/ia1/.
} 
In many respects, the legitimacy challenges presented at least by inconsistent awards and overlapping tribunal membership are not new; scholars have noted the possibility of a legitimacy crisis in investor-state arbitration for a number of years. The Argentine cases do, however, provide reason to revisit these criticisms of the ICSID system, particularly in light of the narrowing of the necessity defense and the failure of the majority of the tribunals to give effect to the NPM provision of the U.S.-Argentina BIT.

What does appear to be new in the Argentine cases, however, is an internal recognition within ICSID itself that the current form and operation of investor-state arbitration may be problematic. In response to the $C M S$ award against Argentina, the Argentine Government filed a request for annulment pursuant to Rule 52 of the ICSID Convention. The September 25, 2007 decision of the Annulment Committee is a surprising and extraordinary piece of jurisprudence. The decision is so remarkable that it seems difficult to interpret it as anything but an attack on the ICSID system from within. The decision carries particular weight because of the membership of the Annulment Committee, which was composed of three of the most respected international lawyers presently practicing. Gilbert Guillaume is the President of the International Court of Justice; Nabil Elaraby is a member of that Court; James Crawford is Whewell Professor of International Law at Cambridge University and the Rapportuer of the International Law Commission on the Draft Articles on the Responsibility of States for Internationally Wrongful Acts.

Article 52 of the ICSID Convention allows for annulment of arbitral awards only on the narrowest of grounds: "that the Tribunal was not properly constituted; that the Tribunal has manifestly exceeded its powers; that there was corruption on the part of a member of the Tribunal; that there has been a serious departure from a fundamental rule of procedure; or that the award has failed to state the reasons on which it was based." Notably the Convention does not provide for review of the legal determinations of the Tribunal, nor does it allow an annulment committee to overturn the award even on the most egregious errors of law. As the MINE Annulment Committee observed: "[A] Tribunal's disregard of the agreed rules of law would constitute a derogation from the terms of reference within which the tribunal has been authorized to function... Disregard of the applicable rules of law must be distinguished form erroneous application of those

\footnotetext{
${ }^{78}$ ICSID Convention, supra note 12, at art. 52.
} 
rules which, even if manifestly unwarranted, furnishes no ground for annulment.”79 Argentina, therefore, argued to the Annulment Committee that the CMS award failed to state the reasons on which its conclusions were based and that the failure to properly apply the NPM clause (Article XI) of the U.S.-Argentina BIT constituted a manifest excess of power. ${ }^{80}$

The CMS Annulment Committee first considered Argentina's claim that the Tribunal had failed to state the reasons on which its conclusion that CMS, the claimant, could enforce the obligations of Argentina to TGN, a subsidiary company. The Annulment Committee agreed with Argentina, finding that "in the end it is quite unclear how the Tribunal arrived at its conclusion that CMS could enforce the obligations of Argentina to TGN....In these circumstances there is a significant lacuna in the award, which makes it impossible for the reader to follow the reasoning on this point." ${ }^{\text {} 81}$ The Committee therefore annulled the decision of the Tribunal on this point. However, due to the severability of the various parts of the award, the Annulment Committee's decision on this point did not impact the remainder of the award.

A second issue addressed by the Committee was whether the Tribunal's failure to give effect to Article XI of the U.S.-Argentina BIT and its consideration of the customary law doctrine of necessity jointly with the NPM provision of the BIT involved a failure to state the reasons for the claim or constituted a manifest excess of power by the Tribunal. The Committee first found that, while the Tribunal's logic was troubling, it had stated the reasons for its decision: “in the Committee's view, although the motivation of the Award could certainly have been clearer, a careful reader can follow the implicit reasoning of the Tribunal." ${ }^{82}$ The Committee then turned to the question of whether the failure to apply Article XI constituted a manifest excess of powers. First, the Committee observed that Article XI of the BIT and the customary defense of necessity are two separate and distinct legal standards: "The two texts having a different operation and content, it was necessary for the Tribunal to take a position on their relationship and decide whether they

\footnotetext{
${ }^{79}$ Maritime International Nominees Establishment v. Republic of Guinea (1989) 4 ICSID Reports 79, 87, at 5.03-5.04.

${ }^{80}$ See CMS Gas Transmission Co. v. Argentine Republic, ICSID Case No. Arb 01/08, Decision of the ad hoc Committee on the Application for Annulment, (Sept. 25, 2007), I 136 [hereinafter CMS Annulment Report].

${ }^{81}$ Id. at 997.

${ }^{82}$ Id., at 9127.
} 
were both applicable in the present case. The Tribunal did not enter into such an analysis, simply assuming that Article XI and Article 25 are on the same footing. In doing so the Tribunal made another error of law."83 Second, the Committee observed that the failure to apply Article XI constituted another error of law: "As admitted by CMS, the Tribunal gave an erroneous interpretation of Article XI. In fact, it did not examine whether the conditions laid down by Article XI were fulfilled and whether, as a consequence, the measures taken by Argentina were capable of constituting, even prima facie, a breach of the BIT. ${ }^{84}$ The Annulment Committee thus attacked the fundamental holding of the award, observing that "These two errors made by the Tribunal could have had a decisive impact on the operative part of the award.”85

Despite finding clear legal errors in the $C M S$ award that presumably impacted the ultimate outcome, the Annulment Committee proceeded to note its own limited powers of review and found that it lacked the jurisdiction to overturn the award. The Committee recalled:

that it has only a limited jurisdiction under Article 52 of the ICSID Convention. In these circumstances, the Committee cannot simply substitute its own view of the law and its own appreciation of the facts for those of the Tribunal. Notwithstanding the identified errors and lacunas in the Award, it is the case in the end that that Tribunal applied Article XI of the Treaty. Although applying it cryptically and defectively, it applied it. There is accordingly no manifest excess of powers. ${ }^{86}$

What makes this Annulment Committee report so unusual is that the Committee had no reason or need to find that the underlying CMS Award was flawed with outcomedeterminative errors. Doctrines of judicial minimalism would dictate that the Tribunal should have decided the issue on the narrowest possible grounds, in this case a simple finding that it lacked the jurisdiction to review the award on anything but a manifest excess of powers and that, lacking such a manifest excess, there was no need for further consideration of the $C M S$ Tribunal's legal conclusions. ${ }^{87}$ Yet, the Annulment Committee

\footnotetext{
${ }^{83}$ Id., at 1 131-132.

${ }^{84}$ Id., at $\mathbf{\Upsilon 1} 135$.

${ }^{85}$ Id., at $\mathbf{9} 135$.

${ }^{86}$ Id., at 9136.

${ }^{87}$ An alternative approach available to the Annulment Committee would have been to find that the errors of law in the award did, in fact, constitute a manifest excess of powers, which would have served as a basis to overturn the award. As Sir Arthur Watts QC has argued: “There comes a stage . . at which a tribunal, in
} 
engaged in an extensive substantive consideration of the Tribunal's findings, stated in no uncertain terms that the Award was legally flawed, and suggested that those flaws were potentially outcome determinative. Careful, conservative, and deliberate international lawyers, such as the members of the CMS Annulment Committee, would not take such an approach without good reason.

Two separate explanations of the Annulment Committee's decision to reach beyond judicial minimalism and critique the substantive basis of the award seem most plausible. The first, quite simply, may have been an effort to prevent the CMS Award from having precedential weight. The Annulment Committee may have found the award and the fact that its analysis was quickly becoming the majority approach in the Argentine cases so legally troubling that it sought to vitiate the award of any precedential value and ensure that subsequent tribunals addressing similar issues did not follow the $C M S$ Tribunal's line of analysis.

While the Committee may well have been attempting to deprive the CMS award of precedential weight, something more may have also been at stake. The Annulment Committee's critique of the CMS Tribunal's award was so blatant and at times even confrontational that the Committee may have been attempting to call into question the legitimacy of the CMS Tribunal and, more generally, a system that lacks appellate review to reverse gross and outcome determinative errors of law. As the Committee observed: "If the Committee was acting as a court of appeal, it would have to reconsider the Award on this ground." 88 One can certainly read into the Annulment Committee’s decision a critical wake-up call to the ICSID system that poor jurisprudence and lack of appellate review authority are an unsustainable combination.

Whether or not the Annulment Committee intended to throw the ICSID system into a crisis of legitimacy with the CMS Annulment Report is something we many never know. The early aftershocks of the CMS Annulment Decision, however, appear to be having just that effect. In the weeks after the Annulment Decision, senior officials in the

purportedly applying a rule of law, gets it so wrong that it must be regarded as having disregarded the rule and not really having applied it at all. The purported application of the rule must be so inadequate, and suffused with such fundamental error, that it transcends the mere commission of an error in applying the law and becomes instead a veritable case of its non-application.” See Opinion of 20 January 2006 annexed to the Respondent's Annulment Reply, I 25, MTD Equity Sdn Bhd.\& MTD Chile v. The Republic of Chile (ICSID Case No. Arb/01/07, Decision on Annulment, 21 March 2007.

${ }^{88}$ CMS Annulment Report, supra note 80, at 9136. 
Argentine government have indicated a desire to reach an agreement with the U.S. publicly clarifying the self-judging nature of the NPM clause in the U.S-Argentine BIT and have made clear that it will be an extreme political challenge for Argentina to pay more than US\$130 million from the national treasury based on award that has been found to be legally erroneous. ${ }^{89}$ At the very least, Argentina, like Bolivia, Uruguay, and Venezuela, may be rethinking its commitment to investor-state arbitration and the ICSID system.

\section{CONCLUSION}

While claims about the legitimacy and viability of investor-state arbitration and the ICSID system are long standing, the Argentine cases present significant new challenges for the system as a whole. By failing to apply the NPM provisions of the U.S.-Argentina BIT, the majority approach in these cases has eroded the flexibility states parties sought to preserve for themselves to respond to extraordinary situations and may have undermined the bargain between investor protection and state freedom of action that at least some states parties thought they had agreed to in their BITs. Similarly, by narrowing the customary defense of necessity to what is effectively a legal nullity, the Tribunals have further encroached on the only other means for states to avoid wrongfulness and liability for actions that harm investors taken in response to serious emergencies. To do so through inconsistent judgments and with reasoning deemed by an annulment committee to be legally erroneous is all the more problematic.

If Argentina were to follow Bolivia's lead and exit the ICSID system, investor-state arbitration would truly face a crisis of confidence. If states do not believe that investorstate arbitration respects their rights, as well as those of investors, they will not consent to the system and that system itself will run the risk of collapse. Before that happens, a deep rethinking of the structure, purposes, and jurisprudence of investor-state arbitration is urgently needed. A variety of solutions have been suggested in the literature, ranging

\footnotetext{
${ }^{89}$ Statement of Osvaldo Guglielmino, Procurador del Tesoro de la Nación Argentina, American University, Washington College of Law, 24 October 2007.
} 
from the creation of appellate review authority to the use of the margin of appreciation as a decision-making framework for the evaluation of state policies that fall within core domains. Now is the time for an urgent consideration of these and other proposals to restore both state and investor confidence in ICSID before it is too late. At the very least, the Argentine cases and the CMS Annulment Report must serve as a wake-up call to ICSID arbitrators to engage in more careful and deliberate legal reasoning that does justice both to the texts of the treaties they are interpreting and the intent of the states parties which drafted those texts. 